\title{
The Kojiki/Nihon Shoki Mythology and Chinese Mythology: Theme, Structure, and Meaning
}

\author{
Xiaofei Tu* and Wendy Xie
}

Citation: Tu, Xiaofei, and Wendy Xie. 2021. The Kojiki/Nihon Shoki Mythology and Chinese Mythology: Theme, Structure, and Meaning. Religions 12: 896. https://doi.org/ $10.3390 /$ rel12100896

Academic Editor: Jeffrey L. Richey

Received: 14 September 2021

Accepted: 14 October 2021

Published: 18 October 2021

Publisher's Note: MDPI stays neutral with regard to jurisdictional claims in published maps and institutional affiliations.

Copyright: (c) 2021 by the authors. Licensee MDPI, Basel, Switzerland. This article is an open access article distributed under the terms and conditions of the Creative Commons Attribution (CC BY) license (https:// creativecommons.org/licenses/by/ $4.0 /)$.
Department of Languages, Literatures, and Cultures, Appalachian State University, Boone, NC 28608, USA; xiew@appstate.edu

* Correspondence: tux@appstate.edu

\begin{abstract}
This essay will compare myths found in the Kojiki and the Nihon Shoki with thematically and structurally similar Chinese myths, and other Japanese texts, in order to shed light on the meanings of both Japanese and Chinese mythology. The authors' approach is partly in the critical textual study tradition that traces back to Gu Jiegang and Tsuda Sokichi, and partly informed by comparative mythologists, such as Matsumae Takeshi, Nelly Naumann, and Antonio Klaus, with attention to Proppian and Levi-Straussian motifs in structural studies. First, we shall discuss some common themes in Chinese and Kojiki/Nihon Shoki myths. Second, we shall point out common structures in both Chinese and Japanese myths. Finally, we shall try to show how such common themes and structures could potentially help us understand the meanings of the myths in discussion.
\end{abstract}

Keywords: mythology; China; Japan; Kojiki; Nihon Shoki

\section{Introduction}

This essay will compare myths found in the Kojiki and the Nihon Shoki with thematically and structurally similar Chinese myths, and other Japanese texts, in order to shed light on the meanings of both Japanese and Chinese mythology. However, similarities between mythologies certainly exist beyond the scope of Chinese and Japanese cultures. As Vladimir Propp wrote, "Just as all rivers flow into the sea, all questions relating to the study of tales lead to the solution of the highly important and yet unresolved problem of the similarity of tales throughout the world" (Propp 1968, p. 16). More recently, Michael Witzel addresses the same similarity in mythology questions as follows, "Even a casual reader is struck by the fact that many myths of origin are very similar to each other, even when they are found in distant parts of the globe and often separated from each other by long periods of time." (Witzel 2013, p. 1). For him, the problem is that:

The standard answers given during the 20th century were either that of a worldwide diffusion from an ancient cultural center such as Egypt or that of universal innate characteristics of the human psyche, such as the archetypes that create similar myths anytime and everywhere. As we will observe, both proposals are not nearly correct or comprehensive enough to explain such widespread concurrences. It is difficult to imagine an early, Bronze Age spread of many important myths across vast continents and wide oceans. It has often been assumed but not yet proved that archetypes employed in the myths mentioned here are universally human and are indeed found all across the globe. (Witzel 2013, p. 3)

The lack of a satisfactory explanation of the similar mythological motifs in different cultures certainly calls for more careful comparative studies. Although the 19th century massive comparative endeavor style of Müller and Frazer has since been harshly criticized for its speculation and overgeneralization (Carroll 1985), many contend that comparative mythology should not be cast away with the proverbial bathing water. As Roman Jakobson maintains: 
Although the steady growth of comparative Indo-European linguistics during the last century was accompanied by parallel efforts at the elaboration of comparative mythology, the development of the latter was retarded by several factors. The methodological shortcomings of the new discipline had a pernicious effect on its concrete results. The shakiness and doubtfulness of its conclusions naturally provoked a negative reaction, but the sound criticism of dubious hypotheses threatened to degenerate into a devastating, even more unfounded hypercriticism, a doctrine of fruitless skepticism. (Jakobson 1985, p. 13)

In reality, many influential mythological approaches are comparative in nature. For instance, a return to structuralist theory is an exciting trend that has been gaining momentum in recent years (Rutherford 2016; Cooper and Guzmen-Carmeli 2020). Although Levi-Straussian structuralism, as Alan Dundes observes, "wears the trappings of structuralism, [this] actual method is a form, an idiosyncratic form to be sure, of the comparative method." (Dundes 1997, p. 39). The study of Japanese mythology has been strongly comparative since the pioneering work of Takagi Toshio in the early 20th century. The contemporary scholar, Obayashi Taryo, considers the comparative approach to be the backbone of Japanese mythological studies (Obayashi 1978, p. 8). In particular, the comparison of Chinese and Japanese mythologies should be an important topic, given the historical and cultural connections between China and Japan.

\section{Sino-Japanese Cultural Exchanges and Mythology}

Cultural exchanges between China and Japan have played an important role in the history of both countries. Examples of continental Asian influences transmitted through, or originating from, China on Japanese institutions, culture, language, and society are too many to count, with the most obvious case being Japan's adaptation of the Chinese writing system. According to the Japanese dictionary, Genkai (言海), 49\% of Japanese words are loanwords from Chinese. China was the first to document Japanese history and language. Indeed, studies on the beginning of Japanese history have been based on Chinese primary sources. The first documentation of the Yamato kingdom appeared in the Book of Han, compiled by the Chinese historian, Ban Gu, on the Eastern Han Dynasty in the first century CE. In a later Chinese historical text, the Records of the Three Kingdoms, the third-century Japanese seemed to live under a form of theocracy (祭政一致) ruled by the shamanessqueen, Himiko. In the sixth century, Confucianism and Buddhism arrived in Japan from China via Korea and, since then, have fundamentally contributed to the shaping of Japanese culture. Prince Shotoku's Seventeen-Article Constitution in the seventh century (Asuka period), the seminal document for Japanese political and social thought, was based upon Confucian and Buddhist concepts freshly imported from the continent. Japanese missions to Tang China in the 7th, 8th and 9th centuries represent Japanese efforts to learn from the strongest and most advanced country in East Asia and to adopt its superior culture. "The nature of these contacts evolved gradually from political and ceremonial acknowledgment to cultural exchanges; and the process accompanied the growing commercial ties which developed over time" (Fogel 2009, p. 107). Some of those who returned to Japan played key roles in the Taika Reforms (645) that brought about greater political centralization and enhanced the power of the imperial court based on the governmental structure of China.

Beyond the above widely acknowledged facts, Suwa Haruo emphasizes the cultural affinity between Japan and ancient southern China and traces their communications to even earlier times. Both the Book of Jin (晋书) Ji Shu, and the Book of Liang (梁书) Liang Shu, hint at connections between Japan and the indigenous people who used to live in southeast China. In $437 \mathrm{BCE}$, the State of $\mathrm{Wu}$ was conquered by the State of Yue and, in 334 BCE, the State of Yue was, in turn, destroyed by the State of Chu. The political turmoil caused large-scale immigration from southern China to Japan. Chugan Engetsu (中嚴円月) a Kamakura-era Buddhist monk, wrote in his The Book on Japan (日本書) that the first Japanese emperor, Emperor Jimmu, descended from Taibo (太伯) of the Wu State (Suwa 2005, p. 54). While such a claim cannot be verified, it is true that there are common 
cultural traits in early Japanese people and the people of $\mathrm{Wu}$ and Yue. Unlike the northern Chinese, who believed that cutting hair and hurting one's own body violated filial piety, both the early southern Chinese and Japanese people had short hair and tattoos all over their bodies. The two peoples also shared a belief in dragons, wore one-piece clothing, and practiced a marriage system in which the husband visited his wife at night and left at dawn. In addition, there was a peculiar practice pertaining to sea travel that was shared by the Chinese and Japanese. When these ancient people traveled on the high seas in a group, one person was selected to fast during the entire trip in order to spiritually safeguard it. If the trip was safely accomplished, this chosen person would be handsomely rewarded. If, on the other hand, disaster struck the voyage, this person would take the blame and be killed. Furthermore, Oka Masao (岡正雄) and Ikehashi Hiroshi (池橋宏) maintain that the aforementioned immigrants from southern China first brought rice to Japan. Miyamoto Nagajiro (宮本長二郎) believed that later immigrating movements around the time of the rise and fall of the Qin Empire were equally significant (Yasumoto 2013, p. 175).

Given the close relationships and frequent cultural imports, it would be safe to discuss the Chinese influence on Japanese mythology on both of the grounds that Witzel has questioned. On the one hand, since the cultural borrowings are so significant, the myth diffusion explanation rests on a solid basis (Hirohata 1977, p. 257). On the other hand, myth interpretations in the psychological approach appear more plausible when conducted on two, very much analogous, cultures. Needless to say, the Chinese influence is by no means to be considered exclusive because studies have shown multifaceted influences, such as Southeast Asian and Altaic sources, existing in the formation of Japanese mythology (Ito 1981, p. 60). Worth mentioning is that Chinese mythology itself is not necessarily purely "Chinese", as it was influenced by outside (e.g., Western Eurasian) civilizations (Carter 2006; Knauer 2006). In addition, the scarcity of existing Chinese myths renders its influence on Japan less obvious but, nevertheless, merits intensive exploration. At the turn of the 20th century, Chinese intellectuals, such as Hu Shih and Lu Xun, blamed the relative dearth of mythological sources in classic Chinese literature on the continuous rationalizing and historicizing efforts by Confucian scholars since the late Zhou Dynasty. In recent years, some have challenged the "myth of the paucity of Chinese myths" (Birrell 1994), but the fact remains that there are no systematic compilations of ancient Chinese mythology comparable to the Japanese Kojiki (古事記) and Nihon Shoki (日本書紀). In this regard, Suwa Haruo's insight may help us. Suwa observes what he describes as the "ripple effect" in the expansion of civilizations. That is, languages, cultural institutions, and political systems tend to evolve and change relatively rapidly in the center of a civilization, while being slow in development and transformation on the peripheries of the same civilization. The implication is that Japan, as the historical periphery of the Chinese civilization, may have preserved many cultural elements that had been lost in the center, China. Along the same lines, Ito Seiji argues that the comparison of the myths of China and Japan not only adds to our understanding of Japanese mythology, but may also be able to recover lost and distorted Chinese mythology that has fallen victim to time and Confucian euhemerism (Ito 1981, p. 253).

In this paper, our approach is partly in the critical textual study tradition that traces back to Gu Jiegang and Tsuda Sokichi, and is partly informed by comparative mythologists, such as Matsumae Takeshi, Nelly Naumann, and Antonio Klaus, with attention to Proppian and Levi-Straussian motifs in structural studies. First, we shall discuss some common themes in Chinese and Kojiki/Nihon Shoki myths. Second, we shall point out common structures in both Chinese and Japanese myths. Finally, we shall try to show how such common themes and structures could potentially help us to understand the meanings of the myths in discussion.

\section{The Kojiki/Nihon Shoki Myths}

For the sake of clarity, we shall lay out an outline of the Kojiki/Nihon Shoki myths. In later analysis, we will add details to the same myths when needed, and tie in thematically 
and structurally relevant Chinese myths and other Japanese texts. The following is the gist of Kojiki and Nihon Shoki.

Myth 1. Izanagi and Izanami

When Heaven and Earth first became active, three solidary gods, namely, Amenominakanushi no kami (天之御中主神), Takamimusuhi no kami (高御産巣日神), and Kamumusuhi no kami (神産巣日神) appeared, who were then followed by seven generations of deities. The seventh and final generation of kami, a male-female pair known as Izanagi no Mikoto (伊邪那岐命) and Izanami no mikoto (伊邪那美命) solidified the earth using a spear and descended on it from heaven (高天原). Izanagi and Izanami married each other and gave birth to the eight islands of Japan, as well as numerous gods. Izanami was then burnt to death while giving birth to the fire god Kagutsuchi no kam i (迦具土神). The deprived Izanagi followed Izanami to the underworld, Yomi (黄泉国). Izanami told her husband that she had already eaten the food of the underworld and asked him not to look at her. An impatient Izanagi lit his comb as a torch only to find that Izanami was now a rotting corpse. The horrified Izanagi ran away and sealed the entrance to Yomi.

Myth 2. Amaterasu and Susanoo

After his visit to Yomi, Izanagi went to purify himself in a river. The three most important kami, Amaterasu omikami (天照大御神), Tsukuyomi no mikoto (月読命), and Susanoo no mikoto (須佐之男命) came into existence when Izanagi washed his left eye, his right eye, and his nose, respectively. Izanagi divided the world among his three children: Amaterasu was allotted the "Plain of High Heaven", Tsukuyomi the night, and Susanoo the seas. Susanoo went up to heaven to see his sister. Numerous children were born between the two gods without physical contact. Susanoo then threw a peeled pied horse into the hall and caused the death of a weaving maid. Because of this, Amaterasu hid herself in the "Heavenly Rock Cave" (天岩戸), plunging heaven and earth into total darkness. The gods, however, were able to trick her out of the cave, restoring light to the world.

For his crimes, Susanoo was expelled from heaven and landed in the land of Izumo, where he slays a monstrous eight-headed serpent (八俣遠吕智) to rescue the earthly goddess, Kushinadahime (櫛名田比売) whom he married.

Myth 3. Okuninushi

Okuninushi (大国主神), also called by other names, such as Onamuji no kami (大 穴牛遅) helped a white hare (and, in return, gained the hare's help) on his way to court the goddess, Yagamihime (八上比売) of Inaba. Okuninushi's jealous brothers killed him twice, but he was revived in both cases. Okuninushi's mother advised that he go to the underworld, Ne-no-Katasukuni (根之堅洲国), where Okuninushi was submitted to a dangerous ordeal by Susanoo, who did not like Okuninushi. Eventually, Okuninushi withstood the trials and ran away with Susanoo's daughter, Suseribime-no-Mikoto (須勢理 毘売).

\section{Myth 4. Ninigi}

Amaterasu's grandson, Hikoho-no-Ninigi-no-Mikoto (日子番能雨雨芸命) was sent to the human world to take it away from Okuninushi, who complied after some hesitation. He married Kohohana-no-Sakuyabime (木花之佐久夜昆売), "Princess of the Flowering Trees", the daughter of Oyamatsumi-no-Kami (大山津見神), the god of mountains, and rejected her elder sister, the homely looking Iwanagahime (石長比売), “Princess of the Eternal Rocks". Hence, Ninigi was doomed to live a life as fleeting as the blossoms of the trees. Sakuyabime became pregnant after spending only one night with Ninigi, causing suspicion in Ninigi. To prove her fidelity, Sakuyabime confines herself inside a sealed birth hut and sets it ablaze as she is about to give birth. She delivered three children in the midst of the fire: Hoderi-no-Mikoto (火照命), Hosuseri-no-Mikoto (火須勎理命), and Hoori-no-Mikoto (火遠理命).

Myth 5. Hoderi and Hoori

Hoderi and Hoori, also known as Umisachihiko (海幸彦), “Luck of the Sea”, and Yamasachihiko (山幸彦), “Luck of the Mountain", were a fisherman and a hunter, respectively. One day, Hoori lost his brother's fishhook in the sea and went into the sea to retrieve 
it. There, he married Toyotamabime (豊玉毘売) daughter of the sea god, Watatsumi-noKami'a (綿津見神). After three years, Hoori goes back to land on the back of a wani. Hoderi became impoverished and succumbed to Hoori.

When Toyotamabime was about to give birth to Hoori's child, she told Hoori not to look. As often happens in mythology, Hoori peeked and found his wife's true form to be that of a wani. Ashamed, she returned to the sea and left the child with the father. The child, Ugayafukiaezu-no-Mikoto (鵜蔁草不合命) grew up to marry his aunt, Tamayoribime (玉依 昆売命). They had four children, one of whom was Kamu-Yamato-Iwarebiko-no-Mikoto (神倭伊波礼昆古命), the first emperor of Japan.

\section{Izanagi/Izanami and Fu Xi (伏羲)/Nü Wa (女媧)}

Hasumi Shigehiko advocates a holistic way of reading and insists that good book can be started anywhere (Hasumi 1982, p. 7). This is perhaps especially true when reading myths. However, for the sake of convenience, we will begin with the first myth listed above. Several Japanese scholars have compared the Izanagi/Izanami myth to the Fu Xi/Nü Wa myth in China (Nakanishi and Matsumura 1990; Kimishima 1989). At first glance, the familiar version of Nü Wa in the redacted Confucian texts seems to have little in common with the Izanagi/Izanami saga. However, as Matsumae Takeshi observes, if we fill in the gaps in the Confucian orthodox versions with details gained from archeological findings, as well as related folk and ethnic stories in China, a comparison of the Izanagi/Izanami myth to the Fu Xi/Nü Wa may produce surprisingly fruitful results (Matsumae 1997-1998, vol. 7, p. 104). Fu Xi has traditionally been considered one of the Three Sovereigns of ancient China. He is also credited with inventing the cultural institution of marriage, and the famous Bagua symbols, as is documented in the Han historian Ban Gu's Bai Hu Tong Yi (白虎通義):

In the beginning there was as yet no moral or social order. Men knew their mothers only, not their fathers. When hungry, they searched for food; when satisfied, they threw away the remnants. They devoured their food, hide, and hair, drank the blood, and clad themselves in skins and rushes. Then came Fu $\mathrm{Xi}$ and looked upward and contemplated the images in the heavens, and looked downward and contemplated the occurrences on earth. He united man and wife, regulated the five stages of change, and laid down the laws of humanity. He devised the eight trigrams, in order to gain mastery over the world.

(Wilhelm 1967, p. 329)

On the other hand, Nü Wa is known in Chinese mythology for saving humanity by patching up the damaged sky, as noted in Huai Nan Zi (淮南子):

Going back to more ancient times, the four pillars were broken; the nine provinces were in tatters. Heaven did not completely cover [the earth]; Earth did not hold up [Heaven] all the way around [its circumference]. Fires blazed out of control and could not be extinguished; water flooded in great expanses and would not recede. Ferocious animals ate blameless people; predatory birds snatched the elderly and the weak. Thereupon, Nüwa smelted together five-colored stones in order to patch up the azure sky, cut off the legs of the great turtle to set them up as the four pillars, killed the black dragon to provide relief for Ji Province, and piled up reeds and cinders to stop the surging waters. The azure sky was patched; the four pillars were set up; the surging waters were drained; the province of Ji was tranquil; crafty vermin died off; blameless people [preserved their] lives. (Liu and Major 2010, p. 224)

While the flood is a common element in world mythologies, the Nü Wa story is unique in that it has both water and fire out of control at the same time on a global scale, a physical impossibility. It seems clear that this story is but a slightly disguised creation story. In addition to the image of a semicreator, Nü Wa was also depicted, together with $\mathrm{Fu} \mathrm{Xi}$, 
as human ancestors. In Du Yi Zhi (獨異志) (c. 846-874 CE), the author, Li Rong, gives this description:

Long ago, when the world first began, there were two people, Nü Kua and her older brother. They lived on Mount K'un-lun. And there were not yet any ordinary people in the world. They talked about becoming husband and wife, but they felt ashamed. So the brother at once went with his sister up Mount K'un-lun and made this prayer: "Oh Heaven, if Thou wouldst send us two forth as man and wife, then make all the misty vapor gather. If not, then make all the misty vapor disperse." At this, the misty vapor immediately gathered. When the sister became intimate with her brother, they plaited some grass to make a fan to screen their faces. Even today, when a man takes a wife, they hold a fan, which is a symbol of what happened long ago. (Birrell 1993, p. 35)

Beyond these oft-quoted classics, scholars have tracked new sources over the last century. In the 1930s, Rui Yifu and Wen Yiduo launched their groundbreaking studies of Fu $\mathrm{Xi} / \mathrm{Nü} \mathrm{Wa} \mathrm{myths} \mathrm{in} \mathrm{the} \mathrm{Miao,} \mathrm{Yao,} \mathrm{and} \mathrm{Dong} \mathrm{ethnic} \mathrm{groups.} \mathrm{With} \mathrm{slight} \mathrm{detail} \mathrm{variations,}$ most of the ethnic myths follow the same main storyline: $\mathrm{Fu} \mathrm{Xi}^{\prime} \mathrm{s}$ father captured the thunder god and locked him in a cage. The father left home for errands after warning his son not to give the jailed thunder god any water. Taking pity on the miserable thunder god begging for water, $\mathrm{Fu} \mathrm{Xi}$ brought him a little drop. The thunder god regained power with access to water and broke away from the cage. As revenge, the thunder god sent down a flood that destroyed humanity. Fu Xi and his sister, Nü Wa, were the only ones who survived. They married and became the ancestors of all humans (Wen 2009). In the above version, the $\mathrm{Fu} \mathrm{Xi/Nü} \mathrm{Wa} \mathrm{story} \mathrm{appears} \mathrm{to} \mathrm{be} \mathrm{a} \mathrm{full-fledged} \mathrm{origin} \mathrm{myth} \mathrm{in} \mathrm{comparison}$ to the fragmented and often enigmatic records in the Han-centric Chinese classics. In recent years, scholarly attention has been directed to hitherto little-noticed documents. For instance, texts in the Dunghuang scrolls from the Late Han to the Five Dynasties period have been brought into discussion. One such text, titled "The Imperial Genealogies since the Beginning of the World" (天地碚已来帝王), tiandi kaipi yilai diwang ji, says,

After a hundred kalpas, the population multiplied. There was not enough food and the strong robbed the weak... Knowing this, the heaven sent down a flood to kill off tens of thousands of people. Only Fu Xi and Nü Wa survived because of their virtues, and they became the heavenly rulers.

复至百劫，人民转多，食不可足，遂相欺夺，强者得多，弱者得少… 天知此恶，即布 下洪水，荡除万人殆尽，唯有伏羲女娲有德存命，遂称天皇.

$\mathrm{Fu} \mathrm{Xi}$ and Nü Wa were siblings, they rode a dragon to the sky and were saved. Seeing the world is in chaos, the Jingang god told them to perform the way of Ying and Yang. They were ashamed and hid in Mount Kun Lun. They surrounded the mountain with $\mathrm{Fu} \mathrm{Xi}$ moving from the left and Nü Wa the right... They became husband and wife.

伏羲女娲 ...兄妹二人, 衣龙上天, 得存其命, 见天下荒乱, 唯金岗天神, 教言可行 阴阳, 遂相差耻, 即入昆仑山藏身, 伏羲在左行, 女娲在右巡行.... 则为夫妇. (Lü 2007, p. 56)

The second paragraph about the first male and female union is strikingly similar to what is told about Izanagi/Izanami in both Kojiki and Nihon Shoki.

Kojiki: And so the mighty one He Who Beckoned proclaimed: "Well then, let us walk around this mighty pillar of heaven and then join in bed." (Yasumaro and Heldt 2014, p. 9)

Niho Shoki: The two Deities thereupon descended and dwelt in this island. Accordingly they wished to become husband and wife together, and to produce countries. So they made Ono-goro-jima the pillar of the centre of the land.' Now the male deity turning by the left, and the female deity by the right, they went round the pillar of the land separately. (Aston 2005, p. 13) 
From the above texts, we have learned that both the Izanagi/Izanami pair and their Chinese counterparts are the first husband and wife, and they consummated their marriage by circling a heavenly pillar. Nü Wa, without male help in the Chinese mythology, was also responsible for repairing (recreating) nature, just as Izanagi and Izanami created the land in the Kojiki and Nihon Shoki. Matsumae finds such similarities in the details of Chinese and Japanese mythologies much more than incidental. For him, both the Chinese version and the Japanese versions could be fragments of an older "more complete" common mythology of the same source. For example, the Chinese classics have repeatedly confirmed that both $\mathrm{Fu} \mathrm{Xi}$ and Nü Wa are in snake forms. It is said in the Rhapsody on the Lu Lingguan Hall (鲁 灵光殿赋), Lu lingguangdian fu, included in the Selections of Refined Literature, one of the earliest and most important anthologies of Chinese literature, that "Fu Xi had a scaled body and Nü Wa was in a snake shape" (伏羲鳞身，女娲蛇躯), Fuxi linshen, nü wa shen qu. The precocious poet of the Three Kingdoms period, Cao Zhi, wrote in his Paean to Nü Wa (女娲 赞 Nüwa zan) that “some say that the two Sovereigns [Fu Xi and Nü W] had human heads and snake bodies" (或云二皇, 人首蛇形), Huoyun erhuang, renshou sheshen.

Material evidence is provided on the Han tomb paintings found in the Wu Family Shrines (built in $151 \mathrm{CE}$ ) in Shandong province, where Fu Xi and Nü Wa are portrayed as half-human and half-snake. They have human heads, and their upper bodies are dressed in human clothing. Below the waists, however, they manifest a serpentine form, with their tails intertwined, symbolizing the male-female union (Rong 1936). Similar images of snake-formed $\mathrm{Fu} \mathrm{Xi}$ /Nü Wa have been found in locations across China, as far as in Turpan in the Xinjiang Uyghur Autonomous Region.

Although there is no explicit mention of Izanagi and Izanami being in snake forms, Matsumae finds circumstantial evidence suggesting that it may well be the case. Yamatohimeno-mikoto (倭姬命), the daughter of Emperor Suinin, served as the first Saio, which was an unmarried female member of the Japanese imperial family sent to the Ise Shrine for ceremonial functions. She morphed into a snake, according to Origins of the Shrines (諸社根 元記), Shoshanemotoki, a 16th century Shinto text. In the 13th century Pilgrimage to the Ise Shrine (大神宮参詣記), Daijingusangeiki, there is a story that snake scales were found under the blanket of another Saio. In Fujuwara Michinaga's diary (御堂関白記), MidoKanpakuki, it is recorded that, in 1005, a fire broke out in the royal palace. The divine mirror, one of the Three Sacred Treasures (三種の神器 sanshu no shinki), was burnt down, revealing a snake behind it (Matsumae 1997-1998, vol. 10, pp. 128-29). These stories suggest that, in the medieval Shinto beliefs, the imperial family was associated with a dragon/snake. By inference, Izanagi and Izanami, to whom the imperial line traces back, should also have the same association.

Matsumae supports his conclusion with details in the Izanagi/Izanami myth. In Kojiki, when Izanagi discovers that his beloved wife has turned into a decaying corpse, he sees the following.

In her head was Grown Thunder.

In her breast was Blazing Thunder.

In her stomach was Darkening Thunder.

In her privates was Splitting Thunder.

In her left hand was Young Thunder.

In her right hand was Earthen Thunder.

In her left foot was Booming Thunder.

In her right foot was Bowing Thunder. (Yasumaro and Heldt 2014, p. 15)

Scholars have speculated on what the Thunders have to do with the underworld but have yet to reach an agreement. Wang Xiaolin notices an obscure reference to the thunder god and pollution in The Commentary of Zuo (左傅), Zuozhuan (Wang 2014, p. 134), while for Matsumae, thunder gods tend to take on the snake form in East Asian mythology, and the 
thunders in the Kojiki myth are snakes often found in tombs. In fact, the Japanese classicist, Takasaki Masahide, contends that the word stems, "nagi" and "nami", in Izanagi's and Izanami's names are related to the word "naga" in South and Southeast Asian languages, and simply mean "snake". The image of a man chased by a snake-shaped woman may have later inspired the folk story and Noh play, Dōjōii (道成寺), in which a woman consumed by love pursues a young man who does not reciprocate her affection and she is eventually turned into a huge snake because of her unenlightened attachment to love (Matsumae 1997-1998, vol. 5, p. 131).

Further elements of the Chinese myth are found on Chengdu Yangzishan (子山) and Chongqing Han tomb paintings, where $\mathrm{Fu}$ Xi holds the Sun in his hands, and Nü Wa the Moon (Matsumae 1997-1998, vol. 5, p. 108). It shows that, as early as the Han Dynasty, $\mathrm{Fu} \mathrm{Xi}$ and Nü Wa were linked to the Yin-Yang principles in general, and to the Sun and the Moon in particular. Matsumae finds a similar association of the Sun and the Moon with Izanagi and Izanami, respectively. According to Nihon Shoki, after his adventures in the earthly and dead worlds, Izanagi retired to the Minor Sun Palace (日之少宮), $\mathrm{Hi}$ nowakamiya. Moreover, worship of the dragon and sea god was closely connected with beliefs in the Sun and Moon gods. In the Kyoto Mito-jinja Shrine (水度神社), the sun god, Amaterutakamimusubi (天照高彌牟須比命), and the sea god, Watatsumitoyotamahime (和多都弥豊玉比売命) are worshiped side by side. The co-worship of the sea and the sun deities is also true at Hirota Shrine(廣田神社), located in Hyogo prefecture. In the Hirakiki Shrine (枚聞神社), in Western Japan, the sea god is believed to be in possession of two magical pearls symbolizing the Sun and the Moon.

On the other hand, Hirohata Sukeo compares the Japanese creation myth to the Chinese myth of Pan Gu (盘古) and sees more similarity between Fu Xi/Nü Wa and the Amaterasu/Susanoo pair (Hirohata 1977, p. 246). In Kogo Shui (古語拾遺), a historical record of the Inbe clan written in the early Heian period, the author, Inbe no Hironari, already referred to Pangu when conveying a sense of suspicion about old traditions: "What happened in the divine era sounds like the Pangu story. To an ill-educated and ill-informed person like me, it seems incredible" (神代之事, 説似盤古, 疑冰之意, 取信定難) (Hirohata 1977, p. 305).

In Chinese sources, Pangu was the primordial giant born of a cosmic egg at the beginning of time. He separated yin from yang with a swing of his giant axe, creating the earth and the sky. When he died, his breath became the wind, mist, and clouds; his voice, thunder; his left eye, the Sun; his right eye, the Moon; his head, the mountains and extremes of the world; his blood, rivers; his muscles, fertile land; his facial hair, the stars and Milky Way; his fur, bushes and forests; his bones, valuable minerals; his bone marrow, precious jewels; his sweat, rain; and the fleas on his fur carried by the wind became animals (Xu n.d.). Hirohata compares Pangu's transformation to many similar stories found in Kojiki/Nihon Shoki, such as the death of Izanami when multiple gods were born out of her dying body:

Because the mighty one She Who Beckoned bore this child, her mighty privates were burned and she fell gravely ill.

From her vomit came the spirit named Metal Mountain Lad, then the spirit named Lady Metal Mountain.

From her excrement came the spirit named Kneading Clay Lad, then the spirit named Lady Kneading Clay.

From her urine came the spirit named Water Gushing Woman, then the spirit named Fresh Growth. (Yasumaro and Heldt 2014, p. 13)

With regard to a living god instead of a dying one, another parallel exists between Pan Gu's eyes turning into the Sun and the Moon, and the birth of the Sun goddess, Amaterasu, and the Moon goddess, Tsukiyomi, out of Izanagi's eyes. Yet one more bodily transformation is in Nihon Shoki, when Izanagi tries to run away from Izanami's hades army, he "made water against a tree, which water at once turn into a great river" (Aston 
2005, p. 25). Izanagi saved himself from his pursuers by transforming his body fluid into a natural stream. In an alternative narrative in Nihon Shiki, after his exile from heaven, Susanoo wanted to create riches for his descendants on the land, "So he plucked out his beard and scattered it. Thereupon Cryptomerias were produced. Moreover, he plucked out the hairs of his breast, which became Thuyas. The hairs of his buttocks became Podocarpi. The hairs of his eye-brows became Camphor-trees" (Aston 2005, p. 58). While the supernatural metamorphoses of gods and humans are a common motif worldwide, such affinities between the details of Chinese and Japanese mythologies are, nevertheless, noticeable, and merit our attention.

In many of the Han tomb paintings mentioned above, Fu Xi and Nü Wa hold a Tsquare (矩), Gui, a measuring tool, and a compass (规), $J u$, in their hands. It is clear from the Chinese classics that the compass and the T-square are symbols of significant cosmic forces. It is stated in Huainanzi that, "the Way is called the compass, the Way is one" (道日 规, 道始于一), and again, “the compass gives life and the T-Square kills" (规生矩杀). The Book of Rites explains that "the ancient kings value the compass and the T-square for their impartiality" (故规矩取其无私 ... 故先王贵之). However, between Fu Xi and Nü Wa in the paintings, there seems to be no set rule on who holds the compass or the T-square. On the basis of Lin Xiaoyu's counts, Fu Xi holds the compass in seven cases, and the T-square in eleven cases, while Nü Wa has the compass twelve times, and the T-square five times. Suggestions have been made that this confusion may have been caused by the mistakes of painters or the evolution of religious beliefs, but these cannot be confirmed (Lin 2019, p. 45).

For Hirohata Sukeo, Fu Xi should hold the compass for the following reason. If we are to believe the Book of Han, $\mathrm{Fu} \mathrm{Xi}$ is just a different name for another mythological figure, Tai Hao (太皞), and in Huainanzi, Tai Hou oversees the spring season, and his symbol is the compass: "the East is Wood. Its god is Tai Hao ... He grasps the compass and governs spring" (The Huainanzi, p. 118). If so, it is unclear why some of the Han tomb paintings do not follow this rule. Hirohata believes that, when $\mathrm{Fu} \mathrm{Xi}$ and Nü Wa are associated with symbols that do not belong to them, it could indicate a depiction of a symbolic exchange between, and a harmonization of, yin and yang forces. The fact that $\mathrm{Fu}$ $\mathrm{X} i$ and Nü Wa are in possession of different symbols on different occasions calls to mind Amaterasu's and Susanoo's exchange of belongings that happens in Kojiki and Nihon Shoki (Hirohata 1977, p. 307):

And so it was that they stood facing each on opposite sides of Heaven's Tranquil Stream and swore sacred oaths.

The great and mighty spirit Heaven Shining began by asking the mighty one Reckless Rushing Raging Man to hand over the sword ten hand spans long that was girded by his side. She broke it into three pieces and rinsed them in Heaven's True Well. Their jewels jingled and jangled as she bit them to bits and spat them all out...

Then the mighty one Reckless Rushing Raging Man asked the great and mighty spirit Heaven Shining to hand over the long strings of curved pendants wrapped around her left looped mighty hair. They jingled and jangled in Heaven's True Well as he bit them to bits and spat them all out. (Yasumaro and Heldt 2014, p. 21)

There is some discrepancy regarding this exchange in Kojiki and Nihon Shoki, and the notoriously large number of variations between similar stories in the Nihon Shoki only make the matter more baffling. In any case, the texts in Kojiki and Nihon Shoki agree that important offspring were produced between Amaterasu and Susanoo as a result of this act, including Amenooshihomimi (天之忍穂耳命), the direct ancestor of the Japanese royal house. Just like the supposed exchange between Fu Xi and Nü Wa accomplishes the harmony of yin and yang, the exchange between Amaterasu and Susanoo made possible the harmony between Amatsukami, "gods of heaven" (天津神), and kunitsukami, "earthly gods" (国津神). Not to be missed is the peculiar detail that both Amaterasu and Susanoo 
produced their children by chewing and spitting. There are actually Chinese precedents in the Daoist tradition. In the Jin Dynasty (265-420CE), the Daoist master Ge Hong wrote The Biographies of Immortals, Shenxian chuan (神仙传), which includes the following fantastic stories: A certain Daoist Ban Meng (班孟), would chew paper and ink and then spit out the pages filled with meaningful sentences; Another Daoist, Liu Rong (柳融), could chew (rice?) powder and eggs came out of his mouth; and the most famous Daoist in the book, Ge Xuan (莺立), a great uncle of Ge Hong, could chew rice and let out wasps (Ge n.d.).

For Hirohata, such borrowing of Daoist concepts and images might have to do with early medieval Japan's efforts to establish a self-identity. The Chinese belief that immortals reside on mountains in remote oceans to the east of China has a long history. The Classics of Mountains and Seas, for instance, talks about a mountain named Penglai (Chen et al. 2010, p. 147). Hirohata believes that the Japanese ruling class made use of Chinese mythology and created a self-image as the land favored by gods (Hirohata 1977, p. 317).

In the Heian period text, titled the Private Commentary on Nihonshoki (日本書紀私記), the author opines: "Japan is where the Sun rises from the Fusang Tree in the East, thus it is called Nippon" (日本國 ..., 日出東方，昇於扶桑，故云日本). Shaku Nihongi (釈日本紀), an annotated text of the Nihon Shoki compiled by Urabe Kanekata in the 13th century, agreed by saying that "our country is in the far east land and close to where the Sun rises. Hence it takes its beautiful name" (本朝地在東極, 近日所出. 又取嘉名).

In the interest of space, we limit our exploration of common themes and cultural references in Chinese and Japanese mythologies to the first two myths on our list. Now we shall turn to the structure of Japanese and Chinese mythologies.

\section{The Structure of Chinese and Japanese Myths}

Ito Seiji, a specialist in Chinese mythology, sees an analogy between the story of Okuninushi and the legendary Chinese emperor, Shun, one of the Five Emperors in Confucian traditions. Shun was first mentioned in Zhou Dynasty texts, such as Mencius and Mozi, and, for two thousand years, had been considered an exemplary historical ruler. It was not until early in the 20th century that the Doubting Antiquity School, led by $\mathrm{Gu}$ Jiegang, cast doubts on the historical reality of the Five Emperors. Since then, many scholars have treated Shun as a mythological figure, and applied methods in the field to Shun stories.

The main plot of the Shun story is that, before becoming an exemplary ruler, Shun was from a humble background. He had a stepmother and a stepbrother who conspired to kill him, and a blind father who was unprotective. The earliest detailed description of the murder attempts on Shun's life is present in Mencius:

Wan Zhang said, "His parents set Shun to repair a granary, to which, the ladder having been removed, Gu Sou (blind old man) set fire. They also made him dig a well. He [was given advice by his two wives beforehand and] got out, but they, not knowing that, proceeded to cover him up. Xiang said, "Of the scheme to cover up the city-forming prince, the merit is all mine. Let my parents have his oxen and sheep. Let them have his storehouses and granaries. His shield and spear shall be mine. His lute shall be mine. His bow shall be mine. His two wives I shall make attend for me to my bed." Xiang then went away into Shun's palace, and there was Shun on his couch playing on his lute. Xiang said, "I come simply because I was thinking anxiously about you." At the same time, he blushed deeply. Shun said to him, "There are all my officers-do you undertake the government of them for me." (Legge 1985)

Despite their evil deeds, Shun remained loyal to his family. Because of his admirable family reverence, Shun was recommended to Emperor Yao. Yao married his two daughters to Shun and eventually passed to Shun his throne.

Ito Seiji points out some structural commonalities between Shun and Okuninushi. Comparing both myths, he notes that: (1) Both Shun and Okuninushi survived trials posed by brother(s) and a father (father-in-law), and eventually were enthroned; (2) Both married 
the old king's daughter(s); and (3) Both were helped by their wife (wives) when enduring the trials (Wang 1988, p. 282). A comparison chart can be made of the two stories (see Table 1):

Table 1. Shun and Okuninushi.

\begin{tabular}{cc}
\hline Shun & Okuninushi \\
\hline $\begin{array}{c}\text { Passed trials by a hostile brother, Xiang, and a } \\
\text { blind father who was an accomplice }\end{array}$ & $\begin{array}{c}\text { Passed trials by 80 hostile brothers and a } \\
\text { hostile father-in-law, Susanoo }\end{array}$ \\
\hline Given advice by Emperor Yao's daughters & $\begin{array}{c}\text { Given advice by Susanoo's daughter, } \\
\text { Suseribime }\end{array}$ \\
\hline Married Emperor Yao's daughters & Married Suseribime \\
\hline Became Emperor & Became the ruler of the land \\
\hline
\end{tabular}

What we begin to sense now is that, in addition to common images and actions, the above two narratives are analogous as wholes. They share a certain inner logic that drives the narratives forward. If we look back at the Kojiki/Nihon Shoki myths armed with this new understanding, we realize that all these myths share a similar underlying structure as well. De Veer has laid out the structure as follows (see Table 2, De Veer 1976, p. 196):

Table 2. Comparisons of Myths 1, 3, 4, 5 .

\begin{tabular}{|c|c|c|c|}
\hline Izanagi/Izanami & Okuninushi & Ninigi & Hoori \\
\hline $\begin{array}{l}\text { Protagonists: } \\
\text { husband and wife }\end{array}$ & $\begin{array}{c}\text { Protagonists: father, } \\
\text { daughter, and } \\
\text { husband }\end{array}$ & $\begin{array}{c}\text { Father, two daughters, } \\
\text { and husband }\end{array}$ & $\begin{array}{c}\text { Protagonists: father, } \\
\text { daughter, and } \\
\text { husband }\end{array}$ \\
\hline $\begin{array}{l}\text { Husband wants wife } \\
\text { to return for } \\
\text { procreation, but she } \\
\text { does not }\end{array}$ & $\begin{array}{l}\text { Husband does not } \\
\text { procreate with wife }\end{array}$ & $\begin{array}{l}\text { Wife and husband } \\
\text { procreate once in one } \\
\text { case, never in the } \\
\text { other }\end{array}$ & $\begin{array}{l}\text { Wife leaves husband } \\
\text { but still desires to } \\
\text { procreate, so sends } \\
\text { for sister }\end{array}$ \\
\hline $\begin{array}{l}\text { Wife will not return } \\
\text { with husband; he } \\
\text { leaves alone }\end{array}$ & $\begin{array}{l}\text { Man and woman } \\
\text { meet, marry without } \\
\text { father's approval, } \\
\text { leave together }\end{array}$ & $\begin{array}{l}\text { Man and woman } \\
\text { meet, wait for father's } \\
\text { approval to marry; } \\
\text { father gives both } \\
\text { daughters to hero; he } \\
\text { returns elderly, has } \\
\text { intercourse once with } \\
\text { younger; he leaves }\end{array}$ & $\begin{array}{c}\text { Man and woman } \\
\text { meet, marry with } \\
\text { father's approval; he } \\
\text { leaves alone }\end{array}$ \\
\hline $\begin{array}{l}\text { Wife and husband } \\
\text { procreate }\end{array}$ & $\begin{array}{c}\text { No mention of wife } \\
\text { and husband } \\
\text { procreating }\end{array}$ & $\begin{array}{l}\text { Hero rejects elder } \\
\text { sister, spends only } \\
\text { one night with } \\
\text { younger }\end{array}$ & $\begin{array}{l}\text { Wife bears one child, } \\
\text { but there is no } \\
\text { mention of sexual } \\
\text { relations }\end{array}$ \\
\hline $\begin{array}{c}\text { Husband returns } \\
\text { without wife and } \\
\text { creates alone }\end{array}$ & $\begin{array}{l}\text { Husband returns with } \\
\text { wife and creates alone }\end{array}$ & $\begin{array}{l}\text { Wife follows husband } \\
\text { in order to give birth } \\
\text { alone }\end{array}$ & $\begin{array}{c}\text { Wife follows husband } \\
\text { in order to give birth } \\
\text { alone }\end{array}$ \\
\hline $\begin{array}{c}\text { Wife is ugly to } \\
\text { husband }\end{array}$ & $\begin{array}{l}\text { Husband is ugly to } \\
\text { father-in-law }\end{array}$ & $\begin{array}{l}\text { Husband is beautiful } \\
\text { to father-in-law, one } \\
\text { wife ugly to husband }\end{array}$ & $\begin{array}{c}\text { Wife is ugly to } \\
\text { husband }\end{array}$ \\
\hline $\begin{array}{l}\text { Wife dies through } \\
\text { giving birth to fire }\end{array}$ & & $\begin{array}{l}\text { Wife lives through } \\
\text { giving birth in midst } \\
\text { of fire }\end{array}$ & \\
\hline $\begin{array}{l}\text { Husband breaks bond } \\
\text { of trust with wife (he } \\
\text { looks at her when } \\
\text { heshould not) }\end{array}$ & & $\begin{array}{l}\text { Husband breaks bond } \\
\text { of trust with wife (he } \\
\text { does not believe in } \\
\text { her faithfulness) }\end{array}$ & $\begin{array}{l}\text { Husband breaks bond } \\
\text { of trust with wife (he } \\
\text { looks at her when } \\
\text { heshould not) }\end{array}$ \\
\hline
\end{tabular}


Izanagi and Izanami joined each other to procreate and then experienced separation between the worlds of the living and the dead; Okuninushi successfully courted Suseribime, who had belonged to the underworld; Ninigi, the grandson of the Sun goddess, had marriages with the daughters of the Mountain god; and Hoori ventured into the deep ocean for his courtship and marriage. Even the siblings, Amaterasu (the Sun goddess) and Susanoo (the god of the ocean and later the underworld), are a couple because they produced a number of important children together. Without trying to oversimplify the rich multilayered texts, we find them all to be discourses about the union, separation, and possible reunion of a male and a female involving two different realms. This is a motif that we would like to pursue more. However, for reasons already mentioned above, Chinese mythological materials are highly fragmented and scattered in the ancient literature. It is fairly difficult to find coherent and sufficiently extensive classical Chinese myths for further structural comparisons. To solve the problem, we shall introduce Chinese and Japanese folktales with similar motifs into the equation. Taking cues from Antonio Klaus (Antonio 1982, p. 19), we consider myths and folktales as intimately linked, the difference between the two being that a myth is, or was believed to be, true by a group of people, and by virtue of its "truthfulness", and it serves certain social functions, such as the justification of political authority. On the other hand, a folktale often shares motifs with myths, but is not considered true (or at least is no longer considered as such). Nevertheless, it also serves certain social functions, however frivolous, such as entertainment or as a way of conveying good manners. As Sarah Iles Johnston argues, the lines distinguishing myth from similar literary genres are always fluid and shifting (Johnston 2018). Furthermore, such distinctions are understood variously in different cultures. Allen L. Miller notes that, in Japan, "folktales and myths have circulated freely among all levels of society; it has also meant that formal distinctions between myth, folktale, and legend, which many folklorists and anthropologists take for granted, are difficult to apply to Japan and indeed to East Asia in general." He further adds that, "in Japan even now, as in Europe some centuries ago, what we call folktales carry religiously significant meanings, either as still-living bearers of religious tradition or as fossils of once-living ones" (Miller 1987, pp. 66-67).

The first folktale that we address is from Omi-no-kuni Fudoki (近江国風土記), whose structure closely resembles the myths in our discussion. In the folklorist Seki Keigo's classification, the tale falls under Folktale Number 400, “Fairy Wife" (天人女房) (Seki 1977).

South of the village Yogo-no-sato in the district of Ika-no-kori, province of Omi, there is a small lake. Eight heavenly maidens once flew down on earth as swans to bathe at the lakeshore, when Ikatomi, from the mountaintop in the west, happened to see their mysterious figures in the distance. Coming near, he saw that they were heavenly maidens and, enchanted by their beauty, he could not leave the place. He quietly sent out his white dog who stole the heavenly feather garment of the youngest, which he then concealed. The seven elder sisters in alarm at the intrusion flew off to the sky, but the youngest, prevented by the loss of her feather garment from returning, became an earth-bound human being. Ikatomi built a house in that place, which because of these events came to be known as Kami-no-ura, and he lived there with the younger sister of the heavenly maidens. And eventually two boys and two girls were born to them ... Later, the mother found her feather garment, and, putting it on, flew back up to heaven. (Miller 1987, p. 68.)

Obviously, this tale deals with the union and separation of a male and a female from different realms, just like the five Kojiki/Nihon Shoki myths do in different forms. To make the story structure even more clear, we present a more complicated plotted tale, Ame-no-wahiko (Seki Keigo Number 425A):

An old man had three beautiful daughters. One day a snake came to his house and asked to marry his daughter. The two older sisters refused, but the kindhearted youngest daughter agreed to the marriage. When the snake came for the 
wedding, he told the youngest daughter to cut off his head with her nail clipper. When it was done, the snake turned into a beautiful young man and revealed himself to be Ame-no-wahiko.

One day, Ame-no-wahiko had to leave for heaven and warned his wife not to open a box he left behind, otherwise he would not be able to return to her. The older sisters tickled the bride's armpit and took away the box when she was off guard. The box was opened and as warned by Ame-no-wahiko, he was not able to come back from heaven.

The bride ascended to heaven in search of Ame-no-wahiko and discovered Ameno-wahiko's father was a terrifying demon who would not accept a human daughter-in-law. The demon made the bride spend the night in a room pestered with centipedes. However, with Ame-no-wahiko's help, she survived the trial. Finally, the demon father-in-law grudgingly accepted her to his family on the condition that the bride and his son could only be together once a year. In rest of the time, they were separated by the Milky Way. (Nihon Koten Bungaku Zenshū n.d.)

In this tale, the gender roles are reversed, with the wife belonging to the earth and the husband to the heavenly realm. In addition, as a final twist, a reunion scene after separation is added to the tale. Without a doubt, the source of this Japanese tale is "The Cowherd and the Weaver Girl," one of the best-known Chinese folktales. There are countless variants of the Chinese tale. Our outline here is based on the Ming Dynasty "Story of The Cowherd and the Weaver Girl" (牛郎织女传) (Zhu n.d.). The story tells of the romance between the Jade Emperor's granddaughter, the Weaver Girl, and his servant, the Gold Boy. Their love was forbidden, and the Gold Boy was thus banished to the human world and became a Cowherd. Helped by sympathetic gods, the Cowherd remembered his previous life and ascended to heaven donning a cow hide. In heaven, the Cowherd managed to steal the Weaving Girl's clothes when she was bathing and the two were reunited. However, the Jade Emperor allowed their reunion on one condition: the Weaving Girl was turned into the star Vega, and the cowherd the star Altair, and placed on opposite sides of the heavenly river (the Milky Way). Once a year, on the seventh day of the seventh lunar month, a flock of magpies would form a bridge to reunite the lovers for a single day. The July 7 th Festival has been celebrated since the Han Dynasty. It is called the Tanabata festival in Japan. In ancient times, women would make wishes to the stars of Vega and Altair in the sky during the festival, hoping to have a wise mind, a dexterous hand (in embroidery and other household tasks), and a good marriage.

Sometimes confused with the "The Cowherd and the Weaver Girl" is the story of Dong Yong (董永), first written down in the Han Dynasty book Biographies of Filial Sons (孝 子传). Both stories are listed as Type 34 in Eberhard's Chinese Folktale Index (Eberhard 1937). Dong Yong was a poor farmer who had sold himself into servitude to pay for his father's funeral. On his way to his new master's house, a woman stopped him and offered to marry him. Initially hesitant because he had no means to support a family, Dong Yong accepted her as his wife eventually. The bride managed to weave ten pieces of brocade for Dong Yong to pay off his debt and nullify his indenture. Afterwards, the bride revealed that she was the heavenly weaving maiden and returned to heaven (Liu 1972).

Miller encodes this type of "divine wife" tale in the following way (Miller 1987, p. 71). In the longer version of these tales, the plot moves from Move 1 to Move 8, while some moves are missing from the short version.

Move 1: Lack (no contact between the earthly and heavenly realms)

Move 2: Appearance of mediating element (heavenly female/male appears)

Move 3: Theft and lack removed (stealing feather garment/clothes)

Move 4: Children as permanent bondage between sacred and profane

Move 5: Secondary mediating element withdrawn (feather-cloak returned/box open) Move 6: Primary mediating element withdrawn, lack reinstituted (wife/husband leaves)

Move 7: Pursuit and struggle 
Move 8: Reunion, lack removed (missing in some tales, conditional in others)

Miller arranges the moves in this matrix:

$(1) \rightarrow(2) \rightarrow(3) \rightarrow(4)$
$(6) \leftarrow \mathrm{X} \leftarrow(5) \leftarrow(4)$
$(6) \rightarrow(7) \rightarrow \mathrm{Y} \rightarrow(8)$

In the matrix, the moves in each vertical column are equivalent (or opposite) in meaning. For instance, moves in the first column have to do with lack, and those in the last column have to do with union. $\mathrm{X}$ and $\mathrm{Y}$ are logical links that should be present but do not appear in the tales. Both the stories of Ame-no-wahiko, and the Cowherd and the Weaver Girl, contain moves 1, 2, 3, 6, and 7, while the Dong Yong tale appears to be less complete and has only moves 1,2 , and 6 .

\section{Interpreting Chinese and Japanese Myths}

Having established the systematic relations between specific features in the Chinese and Japanese myths and tales, where do we go from here? Below we venture to draw out potential meanings of the myths presented in this paper.

At the risk of stating the obvious, myths, in general, are intricate and elusive and do not readily yield up their meaning. They often probe the human condition, but they do so in ways fundamentally alien to rational modes of expression. Myths are known to be symbolic and metaphorical. As Herbert Read had it: "Metaphor is the synthesis of several units of observation into one commanding image; it is the expression of a complex idea, not by analysis, nor by direct statement, but by a sudden perception of an objective relation." That means that vigorous induction and reduction cannot be guaranteed to "pin down" mythic meanings and categorize them in a neatly fashion. "In a sense it cannot be explained in language, because to a person who does not understand it any statement of it is as difficult as the original one, while to a person who does understand it a statement of it has no meaning because no purpose" (Empson 1955, pp. 4, 6). The best we can do is to circumscribe and approximate myths without the illusion of certainty.

We shall begin with the dual myths of Shun and Okuninushi. Ito Seiji believes that the structure of the two myths possibly reflects the practices of adulthood initiation and power transition in ancient societies. That is, a young aspirant candidate for kingship has to pass a series of trials put up by the old king in order to be the latter's successor, taking the power and the old king's daughter. Ito Seiji especially notices one detail in both stories, namely, the lute. When Shun's brother, Xiang, believed that he had successfully murdered Shun, he eagerly went after Shun's weapons and lute, but was conspicuously uninterested in Shun's animals and granaries. Similarly, when Okuninishi was taking away Suseribime from her father, Susanoo, he made sure to steal Susanoo's weapons and lute as well. In ancient times, music was considered to be in possession of magical power. The proper use of music was one of the duties of the ruler, and harmonizing music was concomitant with natural and societal harmony. The lute in both myths is, thus, a symbol of regal authority. In Records of the Grand Historian of China, it is recorded that Shun "played the five-stringed lute and sang the song of South Wind" (舜弹五弦之琴, 歌南风之诗) (Wang 1988, p. 283). Such a social-political reading does not necessarily rule out a cosmic interpretation of the same myths. Hayashi Minao (林已奈夫), on the basis of the tradition that Shun had two pupils in each of his eyes, argues that the eyes are the symbol of the Sun, and the said tradition suggests the image of a Sun god (Wang 1988, p. 306). Pang Sun Joo (방선주) reaches the same conclusion by analyzing the character 舜. According to Pang, the original meaning of the character is the hibiscus plant, which is a sun-loving flower. Moreover, according to the Song era encyclopedia, Readings of the Taiping Era (太平御览), Shun was born in a place named "Peach Mount" (桃丘), and peach is often associated with the sun in East Asian cultures (Xiao 1987, p. 141). Moreover, in The Classic of Mountains and Seas, it says: "Lady Climb Liken, the junior wife of the god Hibiscus (Shun), gave birth to two daughters, Evening Bright and Torch Glare ... the divine power of her daughters was so great that they could light up this region for 100 square leagues" (Chen et al. 2010, p. 147). 
If Shun's daughters have the capacity of magical lightening, it can be inferred that Shun himself is likely a Sun god. Indeed, in the same book, it says: "In the great south wildness, there is a gulf . . . this is where the great Hibiscus (Shun) bathes" (Chen et al. 2010, p. 167). In case we wonder what kind of bathing facility this could be, the book continues:

Below this land lies Hotwater Valley. Up in Hotwater Valley there is the Leaning Mulberry tree. That is where the ten suns are bathed. Hotwater Valley is situated north of Blacktooth land. There is a very big tree standing in water. Nine suns occupy its lower branches, and one sun occupies its topmost branch. (Chen et al. 2010, p. 128)

Kato Joken (加藤常贤) argues that the name of the Hotwater Valley (shang 汤) came from its homonym (shang 商), whose original meaning is "a baby being born" (Tetsui 1990, p. 184). Here, the human birth is mythically related to the daily birth of the Sun. Henri Maspero points out that the original form of the character, "east" (dong 东), is the image of the sun on a tree, while the character "dusk" (yao 杳), is the sun under the tree (Tetsui 1990, p. 145). The mythical idea behind the said myths is that the Sun goes through the underworld every night, resting on a cosmic tree and getting rejuvenated, and comes back to life on a daily basis.

Just like Shun, Okuninushi is closely connected with the Sun image. In Kojiki, when Okuninushi's brothers plotted to kill him, they came with a rather uncommon plan.

And so it was that the eighty spirits grew furious with the spirit Great Iron Mines Noble and plotted together to kill their brother.

When they reached the foot of Mount Gems in the land of Mother Oaks, they spoke to him, saying:

'There is a red boar on this mountain. We will drive it down the mountainside while you wait here to take it. If you do not wait and take it, you will die.'

And so saying, they found a large boulder resembling a boar, heated it in a fire, and rolled it down the mountainside.

And so when they pushed it down the mountainside, he caught it and was immediately burned to death. (Yasumaro and Heldt 2014, p. 29)

In the early Buddhist text, Dharmapada, the Buddha's cousin, Devadatta, tried to replace the Buddha as the head of the Sangha with three attempts at the Buddha's life. The second murder attempt was rolling a rock downhill onto the Buddha's walking path. More explicitly suggestive than in Dharmapada, the fire boulder in Okuninushi's death vividly calls to mind a descending (dying) Sun which is to rise again (to be reborn). As expected of the Sun, Okuninishi was indeed revived in the story. Then, the second patricidal act of Okuninushi's evil brothers was done in the following way:

Now seeing this, the eighty spirits tricked him once again, luring him into the mountains. There they cut down a large tree, drove a wedge into it, and put him aside. Straightway they removed the wedge and he was crushed to death. (Yasumaro and Heldt 2014, p. 30)

Okuninushi's second death was associated with a tree, fitting in perfectly with the Sun tree myth. When he was resurrected the second time, and decided to run away from his siblings on his mother's advice, the tree image emerged once more:

And so the eighty spirits gave chase and caught up with him (Okuninushi). When they nocked arrows to their bowstrings and asked for him to be handed over, the spirit of Woods let him escape by slipping through the fork of a tree. (Yasumaro and Heldt 2014, p. 30)

Finally, Okuninushi's son was symbolically born from a tree. Supposedly, the reason was that the mother was afraid of Okuninushi's jealous chief wife: 
In keeping with their previous marriage pledge, Lady Eightfold Headwater (Yagamihime) was still sleeping with her husband. So he brought her with him, but she feared his chief wife, Lady Bold (Suseribime), and went home, leaving the child she had borne wedged in a tree fork. (Yasumaro and Heldt 2014, p. 32)

According to Matsumae Takeshi, the tree on which the Sun rests is also the axis of the universe. In the Ise Shrine, the center pillar of the main hall is called 忌柱, a symbol of the cosmic tree. The Shinto text, Categorized Origins of Gods (類聚神祇本源) makes it clear that the divine hall with the central pillar is the blueprint of the universe where all gods were created (Matsumae 1997-1998, vol. 5, p. 69).

Carl Hentze stressed the isotopic relation between human and solar rebirth in myths. In particular, he noted that symbolic significance of the folded arms of a fetus. The life force, or light, is depicted in myths as hidden under a god's arms (Hentze 1955, p. 107). In Japanese sources, we find the following examples.

The reader will recall that Ame-no-oshihomimiso was one of the sons between Amaterasu and Susanoo, and later the father of Ninigi, the god sent down from heaven by Amaterasu to rule the land. In Kogo Shui (古語拾遗), it is written: “the Sun goddess Amaterasu loved her son Ame-no-oshihomimiso so much that she always held him under her arms. Hence, he was called the armpit son"(天照大神, 育吾勝尊, 特甚鍾愛, 常懷腋下, 稱日 腋子). To substantiate this story, an obviously false etymology was created by the book that the word "my son" (wakako) was derived from "armpit son" (wakeko). The second case is about Prince Otomo, who was the crown prince supposed to inherit his father Emperor Tenchi's throne. Eventually, the throne was usurped by his uncle, Emperor Tenmu, and, as a result, Prince Otomo was killed. The poetry collection, Kaifuso (懷風藻), documented an ill omen before the usurpation happened. Prince Otomo dreamt one night that "the sky opened up, an old man in red came down with the Sun in his hands and about to pass it to the Prince. Suddenly a man appeared under the old man's arm and snatched the Sun." (嘗夜夢, 天中洞啓, 朱衣老翁, 捧日而至. 擎授王子. 忽有人, 從腋底出來, 奪將去) (Ito 1981, p. 56).

The death and re-rising spectacles are not only limited to the Sun. Here, let us revisit an episode in the Okuninushi myth when Okuninushi encountered a white hare before his first marriage, sometimes considered an insignificant detail, but one that is, in fact, highly relevant:

The hare replied, saying:

"Your servant was on Isle in the Offing and wanted to cross over to this land, but there was no way for me to do so. So I tricked a sea beast into helping me saying:

“'Let us see who has more kin, you or I. you will bring all your kin and make them form a straight line from this island to Attendant Cape. Then I will run over them and take count as I race across. That way we will know which of us has more relatives.'

"And so saying, I persuaded them to lie down in a line and then ran over them, counting as I raced across. As I was about to reach land, I spoke, saying:

"'I have tricked you!'

"Straightaway the last sea beast in the line grabbed hold of me with its teeth and tripped me of my fur robe." (Yasumaro and Heldt 2014, p. 28)

Klaus Antoni has proven that the naked hare, robbed of his coat by the crocodile, is the moon-rabbit, which is devoured and disgorged by darkness. Thus, the seemingly lighthearted animal tale is, in fact, "a puzzle of truly cosmic proportions" (einem Rätsel von wahrhaft kosmischem Ausmaß) (Antonio 1982, p. 291). Okuninushi helps the hare to a new skin and, hence, sets the world in order once again, for death, symbolized by the skinning, must be followed by new life, which is endowed by the new skin (Antonio 1982, pp. 289-92). Always multilayered and multidirectionally signifying, the white hare myth also has significant bearings on human existence, which is understood as a cycle of death 
and reincarnation. The sea beasts in Kojiki, possibly crocodiles, are residents in water (the other world), while the hare belongs to land. When a crossover between land and water, that is, the worlds of the living and the dead, takes place, the story seems to be concerned with the equilibrium between the two worlds. The counting of land and sea animals is saying that the numbers of people to die, and souls to be reincarnated, need to be in a good balance. Expressing both the macrocosmic (universe) and microcosmic (human) levels, as Antoni puts it, "the entire world view present here is based on the conception that death must be followed by new life. The moon does not ellipse and forever remained concealed. In the same manner as the young life is freed from the hereafter and the initiated can return to the world of the living, so does the moon emerge again out of the darkness" (Antoni 1982, p. 156).

Indeed, in addition to acting out the constant cosmic drama of rebirth and renewal, the Sun, and other celestial bodies, are often considered to be vehicles, carrying the souls of the dead to heaven (Matsumae 1997-1998, vol. 10, p. 22). Cosmic revival myths are isogenic, with myths defining the human life cycle. The same symbolism refers to the cosmic range as does to the human one.

Now we can look back at the stories about the male and female union and separation in a different light. The Kojiki/Nihon Shoki myths, together with the folktales that we have analyzed, pose a structural contradiction between mortal/human/profane and immortal/divine/sacred, and "bear exclusively upon the utmost existential opposites, life and death" (Naumann 1982, p. 15). Izushi Yoshihiko (出石誠产) was among the first scholars to point out that the Milky Way that separates the Cowherd and the Weaver Girl is the pathway for the souls of the dead to ascend to heaven (Katsumata 2017, p. 365). Indeed, the July Seventh Festival in China, and Tanabata in Japan, have their roots in the Ghost Festival (Zhongyuan jie (中元节), and later, Yulanpen jie (孟兰盆节), in the Buddhist tradition). It is the time of the first quarter Moon, symbolizing the rebirthing celestial deity. In Hagoromo (羽衣), a Noh adaptation of the heavenly maid tale, a line of lyrics sings: "The jeweled axe takes up the eternal renewing, the palace of the moon-god is being renewed with the jeweled axe, and this is always recurring" (Pound 1971, p. 35). Naumann believes that the Weaver Girl's work is to "weave," that is, to produce and replenish celestial light, noticing the connection between the two characters, "weaving woman", 工, and "witch", 來, with the two horizontal and one vertical strokes in both characters symbolizing a shamanic figure who joins this world and the world above (Naumann 1982, p.28). The first quarter of a month is also a time for souls to be released from suffering and ready themselves for rebirths. In East Asian literature, the Moon and the sentiment about the transience of human life are almost always coexistent. In Poem 1270 of Manyoshu, for instance, it says "Moonlights on the Hatsuse Mount is a reminder that human life is impermanent like the shape of the Moon” (隠口乃泊瀬之山丹照月者盈ち為焉人之常無). The Magpie Bridge in the Chinese story is the ferry that carries souls to their heavenly destination. In fact, Hentze noticed that Chinse characters with the bird radical are sometimes associated with meanings of "awe" and "fear", reminiscent of the morbid connection between birds and death in times gone by: 懼 is plain terror, while 誰 is an object so dreadful that its name is not to be mentioned (Hentze 1974, p. 38). However, because souls need to be reborn and come back to the human world through sexual acts and pregnancy, macabre ghost stories inevitably turned into softhearted romances, as the Cowherd and the Weaving Maiden story and the Magpie Bridge are immortalized in Qin Guan's (秦观) poem:

Through the varying shapes of the delicate clouds,

the sad message of the shooting stars,

a silent journey across the Milky Way.

One meeting of the Cowherd and Weaver amidst the golden autumn wind and jade-glistening dew,

eclipses the countless meetings in the mundane world.

The feelings soft as water, 
the ecstatic moment unreal as a dream,

how can one have the heart to go back on the bridge made of magpies?

If the two hearts are united forever,

why do the two persons need to stay together-day after day, night after night?

(Qiu 2003, p. 133)

Even in contemporary East Asian literature, the Milky Way image is symbolically linked to sexual relations, death, or both at the same time. In Natsume Soseki's novel, The Gate, a sex scene is subtly described by a reference to the Milky Way: "The two [Sosuke and Oyone] spoke no further of the matter but laid out their bedding for the night and went to sleep. High above them as they slept the stars of the Milky Way shone down coolly" (Natsume 2006, p. 52). In the famous ending scene of Kawabata's Snow Country, the hero witnesses the incidental death of a girl with whom he is emotionally involved. The novel describes the shocked and saddened hero in these words: "As he caught his footing, his head fell back, and the Milky Way flowed down inside him with a roar" (Kawabata 1971, p. 142).

Now we return from heaven to the earth for more afterlife symbols. We discussed above the snake image in the Izanagi/Izanami myth. As Michael W. Kelsey points out, "one could list story after story in which reptilian deities are linked strongly to the dead. These are essentially chthonic deities, and their association with fertility on the one hand, and the world of the dead on the other is worldwide." Moreover, "the underworld is seen here as a source of life, and it is deemed possible for a mortal ... to seize these powers from the world of the dead." (Kelsey 1981, pp. 225-26)

Katsumata seriously asks a seemingly trivial question regarding heavenly wife tales: why would a heavenly maiden want to bathe on earth? (Katsumata 2017, p. 353) Part of the answer is that, in myths, heaven, the world beneath the surface of the earth, and the water world (oceans, rivers, lakes, etc.) are all held to be locations of the world of the dead. Yoshino Hiroko notes that, in ancient Chinese beliefs, floods are associated with the negligence of sacrifice to ancestral spirits (Yoshino 2003). Animal sacrifices and human offerings to a river god, as happens in the Susanoo myth, have as much to do with agricultural ceremonies as appeasement to the deceased. Thus, a heavenly creature's ablution on earth is a mediating act between the two worlds. A second related reason seems to be that, in mythical thinking, women's unique role in procreation shows a bond between them and the souls fated to reside in their wombs (Malinowski 1987). As noted above, the other world that the fabled wife belongs to is a source of both riches and pollution. In both the Kojiki/Nihon Shoki myths and the heavenly wife tales, the husband obtains children, and sometimes newfound wealth, through his wife. However, for her association with the other world, the wife needs to clean herself, prove her purity (chastity), and eventually leave when her true form is revealed.

\section{Conclusions}

Above, we have first demonstrated that the Kojiki/Nihon Shoki myths and Chinese myths share some common themes and analogous details. Moreover, we have discovered the underlying structures of the same myths with the help of Chinese and Japanese folktales. On the basis of the thematic and structural comparisons, we have arrived at tentative conclusions about the meanings of these myths. As discussed at the beginning of this essay, Chinese cultural influences on premodern Japan had been wide-ranging and in-depth. This is also true in the case of mythology. Scholars have explored the Chinese elements in Japanese mythology from various angles. For instance, Komine Kazuaki (小峯和明) investigates the linguistic and stylish borrowings from Chinese literature in the composition of the Kojiki/Nihon Shoki myths (Komine 2013). In contrast, the authors of this essay hope to demonstrate an affinity between Chinese and Japanese mythology that goes beyond semantic and literary loans and into deeper levels of the encoding and configuration of the myths. 
Finally, what have we learned from the myths and folktales in our discussion? All told, the myths that we have discussed are based on the knowledge that life becomes possible only through death, at both the human and cosmic levels (Naumann 1982, p. 30). As Antoni puts it, "our understanding of death as an absolute end, a complete decomposition and as the end of existence hinders our entrance" to the mythical thinking, "in which death obviously does not mark the end of existence but is rather regarded as a transformation of the manner of being" (Antoni 1982, pp. 153, 157). To modern minds, such mythical thinking may sound naïve and wishful. However, could it contain wisdom that would enlighten us about our existence? As Hentze puts it: “Das Geheimnis der Schöpfung ist hier, ist dort, ist überall, order aber, es ist nirgends, wenn es nämlich nicht erlebt wird. Doch dienen Mythe und daran anschließende Darstellung mit ihren Symbolen dem Zweck, möglichst dicht an die Erlebnismöglichkeiten des Geheimnisses heranzuführen"("The secret of creation is here, is there, is everywhere, or, it is nowhere if it is not experienced. But these myths and the subsequent representation with their symbols serve the purpose of bringing us as close as possible to the possibilities of experiencing this secret") (Hentze 1955, p. 191).

Author Contributions: Conceptualization, X.T.; methodology, X.T. and W.X.; investigation, X.T. and W.X.; resources, X.T. and W.X.; data curation, X.T. and W.X.; writing-original draft preparation, X.T.; writing-review and editing, X.T. and W.X. All authors have read and agreed to the published version of the manuscript.

Funding: This research received no external funding.

Conflicts of Interest: The authors declare no conflict of interest.

\section{References}

Antoni, Klaus. 1982. Death and Transformation: The Presentation of Death in East and Southeast Asia. Asian Folklore Studies 41: 147-62. [CrossRef]

Antonio, Klaus. 1982. Der weisse Hase von Inaba-Vom Mythos zum Märchen: Analyse eines japanischen "Mythos der ewigen Wiederkehr" von dem Hintergrund altchinesischen und zirkumpazifischen Denkens. Wiesbaden: Steiner.

Aston, William George. 2005. Nihongi: Chronicles of Japan from the Earliest of Times to A.D.. Clarendon: Tuttle Publishing.

Birrell, Anne. 1993. Chinese Mythology: An Introduction. Baltimore: Johns Hopkins University Press.

Birrell, Anne. 1994. Studies on Chinese Myth Since 1970: An Appraisal, Part 1. History of Religions 33: 380-93. [CrossRef]

Carroll, Michael P. 1985. Some Third Thoughts on Max Müller and Solar Mythology. European Journal of Sociology 26: 263-90. [CrossRef]

Carter, Martha L. 2006. China and the Mysterious Occident: The Queen Mother of the West and Nanā. Rivista Degli Studi Orientali (New Series) v79/n1-4: 97-129.

Chen, Chengjin, Hong Wang, and Zhengying Zhao. 2010. Shan hai jing = The Classic of Mountains and Seas. Changsha: Hu nan ren min chu ban she.

Cooper, Samual, and Shlomo Guzmen-Carmeli. 2020. The Structure of Change: A Structural Interpretation of the Biblical Story of Joseph. Religions 11: 8. [CrossRef]

De Veer, Henrietta. 1976. Myth Sequences from the Kojiki: A Structural Study. Japanese Journal of Religious Studies 3: 175-214. [CrossRef]

Dundes, Alan. 1997. Binary Opposition in Myth: The Propp/Levi-Strauss Debate in Retrospect. Western Folklore 56: 39-50. [CrossRef]

Eberhard, Wolfram. 1937. Typen Chinesischer Volksmärchen. Helsinki: Suomalainen Tiedeakatemia.

Empson, William. 1955. Seven Types of Ambiguity. New York: Noonday Press.

Fogel, Joshua A. 2009. Articulating the Sinosphere: Sino-Japanese Relations in Space and Time. Cambridge: Harvard University Press.

Ge, Hong. n.d. Shenxiao Zhuan神仙传. Available online: https:/ / ctext.org/shen-xian-zhuan/zhs (accessed on 9 August 2021).

Hasumi, Shigehiko. 1982. Shōsetsuron hihyōron小説論 = 批評論. Tokyo: Seidosha.

Hentze, Carl. 1955. Tod, Auferstehung, Weltordnung: Das mythische Bild im ältesten China, in den Grossasiatischen und Zirkumpazifischen Kulturen. Zürich: Origo Verlag.

Hentze, Carl. 1974. Chinese Tomb Figures: A Study in the Beliefs and Folklore of Ancient China. New York: AMS Press.

Hirohata, Sukeo. 1977. Ki Ki shinwa no kenkyū: sono seiritsu ni okeru Chūgoku shisō no yakuwari記紀神話の研究: その成立における中国思 想の役割. Tokyo: Kazama Shobō.

Ito, Seiji. 1981. Nihon shinwa to Chügoku shinwa日本神話と中国神話. Tokyo: Gakuseisha.

Jakobson, Roman. 1985. Contributions to Comparative Mythology: Studies in Linguistics and Philology, 1972-1982. Berlin: Mouton.

Johnston, Sarah Iles. 2018. The Story of Myth. Cambridge: Harvard University Press.

Katsumata, Takashi. 2017. Jōdai nihon no shinwa densetsu man'yōka no kaishaku 上代日本の神話・层説 · 万葉歌の解釈. Tokyo: Ōfū.

Kawabata, Yasunari. 1971. Snow Country. New York: Berkley Publishing Corporation.

Kelsey, Michael W. 1981. The Raging Deity in Japanese Mythology. Asian Folklore Studies 40: 213-36. [CrossRef]

Kimishima, Kisako. 1989. Higashiajia no sōsei shinwa東アジアの創世神話. Tokyo: Kōbun dō. 
Knauer, Elfriede R. 2006. The Queen Mother of the West: A Study of the Influence of Western Prototypes on the Iconography of the Taoist Deity. In Contact and Exchange in the Ancient World. Edited by Victor H. Mair. Honolulu: University of Hawai'i Press, pp. 62-115.

Komine, Kazuaki. 2013. Nihon bungaku-shi. Kodai chūsei-hen日本文学史. 古代・中世編. Tokyo: Mineruva Shobō.

Legge, James. 1985. The Works of Mencius. Oxford: Clarendon Press, Available online: https://ctext.org/mengzi/wan-zhang-i (accessed on 1 September 2021).

Lin, Xiaoyu. 2019. Handai fuxi nüwatuxiang guiju kao汉代伏羲女娲图像规矩配置考. Wenwu jianding yu xinshang文物鉴定与鉴赏 7: $44-45$.

Liu, Xiang. 1972. Xiao zi chuan孝子傳. Taibei Xian Banqiao Shi: Yi wen yin shu guan, Available online: https://zh.m.wikisource.org/ zh-hans/\%E5\%AD\%9D\%E5\%AD\%90\%E5\%82\%B3 (accessed on 9 August 2021).

Liu, An, and John S. Major. 2010. The Huainanzi: A Guide to the Theory and Practice of Government in Early Han China. New York: Columbia University Press.

Lü, Wei. 2007. Chudi boshu, Dunhuang canjuan yu fojiao weijing zhongde fuxi Nüwa gushi楚地帛书, 敦煌残卷与佛教伪经中的伏羲女 娲故事. In Nüwa wenhua yanjiu女娲文化研究. Edited by Zhou Tianyou. Wuhan: Hubei renmin shubanshe.

Malinowski, Bronislaw. 1987. Sexual Life of Savages. Boston: Beacon Press.

Matsumae, Takeshi. 1997-1998. Matsumae Takeshi chosakushū 松前健著作集. Tokyo: Ōfū, 12 vols.

Miller, Allen L. 1987. The Swan-Maiden Revisited: Religious Significance of "Divine-Wife" Folktales with Special Reference to Japan. Asian Folklore Studies 46: 55-86. [CrossRef]

Nakanishi, Susumu, and Masaie Matsumura. 1990. Nihon bungaku to gaikoku bungaku: nyūmon hikaku bungaku日本文学と外国文学: 入 門比較文学. Tokyo: Eihosha.

Natsume, Soseki. 2006. The Gate. London: Peter Owen.

Naumann, Nelly. 1982. "Sakahagi": The "Reverse Flaying" of the Heavenly Piebald Horse. Asian Folklore Studies 41: 7-38. [CrossRef]

Nihon Koten Bungaku Zenshū. 36, Otogi Zōshishū. Available online: https://www.zhz.wiki/blog/ja/\%E5\%A4\%A9\%E7\%A8\%9A\% E5\%BD\%A6\%E8\%8D\%89\%E5\%AD\%90 (accessed on 9 August 2021).

Obayashi, Taryo. 1978. Nihon Shinwa No Kigen日本神話の起源. Tokyo: Kadokwa Shoten.

Pound, Ezra. 1971. Certain Noble Plays of Japan. Dublin: The Cuala Press.

Propp, Vladimir. 1968. Morphology of the Folktale. Austin: University of Texas Press.

Qiu, Xiaolong. 2003. Treasury of Chinese Love Poems. New York: Hippocrene Books.

Rong, Geng. 1936. Han Wu liang ci hua xiang lu: fu kao shi漢武梁祠畫像錄: 附考釋. Beiping: Kao gu xue she.

Rutherford, Danilyn. 2016. How Structuralism Matters. HAU: Journal of Ethnographic Theory 6: 61-77. [CrossRef]

Seki, Keigo. 1977. Nihon No Mukashibanashi: Hikaku Kenkyū Josetsu日本の昔話: 比較研究序説. Tokyo: Nihon Hōsō Shuppan Kyōkai.

Suwa, Haruo. 2005. Nihon ōken shinwa to chügoku nanpō shinwa日本王権神話と中国南方神話. Tokyo: Kadokawa Shoten.

Tetsui, Yoshinori. 1990. Chügoku shinwa no bunka jinruigakuteki kenkyū 中国神話の文化人類学的研究. Tokyo: Hirakawa Shuppansha.

Wang, Xiaolian. 1988. Shen yu shenhua神與神話. Taibei Shi: lianjin chuban shiye gongsi.

Wang, Xiaolin. 2014. Nitchū hikaku shin'wagaku日中比較神話学. Tokyo: Kyūkoshoin.

Wen, Yiduo. 2009. Fuxi kao 伏羲考. Shanghai: Shanghai guji chubanshe.

Wilhelm, Richard. 1967. I Ching. Princeton: Princeton University Press.

Witzel, Michael. 2013. The Origins of the World's Mythologies. New York: Oxford University Press.

Xiao, Bing. 1987. Chuci yu Shenhua 楚辞与神话. Nanjing: Jiangsu guji chubanshe.

Xu, Zheng. n.d. Sanwu liji三五历记. Available online: https://zh.m.wikisource.org/zh-hans/\%E4\%B8\%89\%E4\%BA\%94\%E6\%9B\%86 $\%$ E8\%A8\%98 (accessed on 9 August 2021).

Yasumaro, Ō no, and Gustav Heldt. 2014. The Kojiki: An Account of Ancient Matters. New York: Columbia University Press.

Yasumoto, Biten. 2013. Nihon minzoku no tanjō: kannihonkai kominzoku to chōkō ryūiki bunka no yūgō 日本民族の誕生: 環日本海古民族と 長江流域文化の融合. Tokyo: Benseishuppan.

Yoshino, Hiroko. 2003. In'yō gogyō to Nihon no bunka: uchū no hōsoku de himerareta nazo o toku陰陽五行と日本の文化: 宇宙の法則で秘め られた謎を解く. Tokyo: Daiwa Shobō.

Zhu, Mingshi. n.d. Niulang zhinü 牛郎織女. Available online: https: / / ctext.org / wiki.pl?if=gb\&res=53597\&remap=gb (accessed on 9 August 2021). 